\title{
Diverse population dynamics of three Anopheles species belonging to the Triannulatus Complex (Diptera: Culicidae)
}

\author{
Teresa Fernandes Silva-do-Nascimento/ ${ }^{+}$, Ricardo Lourenço-de-Oliveira
}

Laboratório de Transmissores de Hematozóarios, Instituto Oswaldo Cruz-Fiocruz, Av. Brasil, 4365, 21040-900 Rio de Janeiro, Brasil

The Triannulatus Complex of Anopheles (Nyssorhynchus) consists of at least three sibling species, namely Anopheles triannulatus s.s., Anopheles halophylus and a third undescribed member herein referred to as An. triannulatus "C". Sympatric anophelines belonging to species complexes, even though closely related, may exploit different environments such as larval habitats. In this paper we hypothesize that rainfall and seasonal flooding would distinctly influence the availability of larval habitats and consequently the seasonal population dynamics of sympatric members of the Triannulatus Complex. A reflection of this is distinct seasonal biting frequencies exhibited by three members of the Triannulatus Complex at a site in Central Brazil. Population dynamics seem to be influenced by the water level in the local rivers, although biting frequency of all three species was negatively influenced by rainfall. An. triannulatus s.s. was more abundant following the end of the rainy season, but notably 30 to 60 days after flooding. On the other hand, An. halophylus and An. triannulatus $C$ peaked during the middle of the dry season, when water impoundments have no inflow, are somewhat reduced in size and the water becomes brackish. Differences in population dynamics were greater between An. triannulatus s.s. and An. halophylus and An. triannulatus $C$ than between An. halophylus and An. triannulatus $C$. This might reflect differences in larval habitat exploitation and therefore spatial segregation among these members of the complex.

Key words: Anopheles triannulatus - Anopheles halophylus - Triannulatus Complex - seasonal frequency

The Triannulatus Complex consists of at least three sibling mosquito species: Anopheles triannulatus s.s. (Neiva \& Pinto), Anopheles halophylus Silva-do-Nascimento and Lourenço-de-Oliveira, and a third undescribed species, hereafter referred to as An. triannulatus " $C$ ", that can be differentiated by both isoenzyme and morphological characters (Silva-do-Nascimento et al. 2006). Molecular studies with specimens belonging to the Triannulatus Complex from a site in Central Brazil demonstrated that there is a barrier to gene flow among these three sympatric forms (Silva-do-Nascimento et al. 2006).

An. triannulatus s.l. is considered to be essentially zoophilic, exophilic and crepuscular, although it may bite humans indoors and play a secondary role in malaria transmission when in high densities (Deane et al. 1948, Charlwood \& Wilkes 1981, Lourenço-de-Oliveira \& Luz 1996, Tadei et al. 1998, Brochero et al. 2006, Zimmerman et al. 2006, Póvoa et al. 2006, Rosa-Freitas et al. 2007). Thus, low rates of $P$. falciparum and $P$. vivax s.l. circumsporozoite protein have been reported for $A n$. triannulatus s.l. under natural conditions (Oliveira-Ferreira et al. 1990, Branquinho et al. 1993, Tadei \& Dutary-Thatcher 2000, Póvoa et al. 2001, Galardo et al. 2007).

Financial support: PAPES IV-Fiocruz

${ }^{+}$Corresponding author: tsilva@ioc.fiocruz.br

Received 10 August 2007

Accepted 12 December 2007
An. triannulatus s.s. is widely distributed throughout South and Central America, ranging from Argentina to Nicaragua, and was recently reported in Trinidad, West Indies (Faran \& Linthicum 1981, Chadee \& Wilkerson 2005). An. triannulatus s.s. breeds preferentially in partially shaded or sunlit habitats such as fresh water swamps, lakes, permanent ponds, ditches and river margins, generally associated with emergent graminaceous, submerged macrophytes and floating vegetation such as Pistia sp. (Cerqueira 1961, Faran 1980). This species may breed in residual freshwater left after gold mining, although exploitation of man-made environments is unusual (Lopes \& Lozovei 1995, Ribeiro 2000, Silva 2002).

Until now, An. halophylus and An. triannulatus $\mathrm{C}$ are known only from Salobra, Miranda municipality, Centralwestern region of Brazil, where they occur in sympatry with An. triannulatus s.s. (Silva-do-Nascimento \& Lourençode-Oliveira 2002, Silva-do-Nascimento et al. 2006). Immature stages of An. halophylus were found in a sunlit swamp and in a temporary brackish water lake with abundant floating vegetation, primarily Salvinia sp. Both the swamp and temporary lake were formed during flooding of the Miranda River (MR) in the state of Mato Grosso do Sul (MS), Brazil (Silva-do-Nascimento \& Lourenço-deOliveira 2002). Thus, the overall characteristics of $A n$. halophylus larval habitats seem to be similar to those of An. triannulatus s.s., except for water salinity. Chemical analyses of the water from an An. halophylus habitat showed a high concentration of $\mathrm{NaCl}(2-4 \mathrm{~g} / \mathrm{l})$. Laboratory rearing of An. halophylus was accomplished when larvae were kept in brackish water from such breeding sites, whereas $A n$. triannulatus s.s. breeds in fresh water (Silva-doNascimento \& Lourenço-de-Oliveira 2002). The larval habitats of An. triannulatus $\mathrm{C}$ are unknown. 
In general, population densities of An. triannulatus s.l. in South America seem to increase during the rainy season or during the transitions between dry and rainy seasons (Deane et al. 1948, Lourenço-de-Oliveira et al. 1989, Rebêlo et al. 1997, Ianelli et al. 1998, Xavier \& Rebêlo 1999, Souza-Santos 2002). High capture rates of An. triannulatus s.l. have been reported during periods of flooding in the rainy season or during reservoir replenishment in Brazil (Teodoro et al. 1995, Guimarães et al. 2004). Seasonal distribution and biting patterns of An. halophylus and An. triannulatus $\mathrm{C}$ remain unknown.

Closely related members of anopheline species complexes have been shown to exploit different environments and to exhibit distinct ecological attributes such as preference for fresh versus brackish water, especially when in sympatry (Coluzzi et al. 1979, Edillo et al. 2004). Therefore, although niche partitioning by members of species complexes is expected, it is thought that gravid females would preferentially select oviposition sites depending on species (Edillo et al. 2006). Very little is known about differences in larval and adult habitat usage by the three members of the Triannulatus Complex. In the present paper, we test the hypothesis that population dynamics of sympatric members of the Triannulatus Complex are distinctly influenced by rainfall and periods of peak of river flow that impact on availability and water characteristics of larval habitats.

\section{MATERIALS AND METHODS}

Study area - Mosquito collections were performed in Salobra (20 12'40" S, 56 29'30" W), Miranda municipality, MS, in Central-western Brazil. Salobra is located at the margin of the MR in the Brazilian Pantanal. Pantanal (literally 'huge swamp') is the world largest freshwater wetland, nearly $140,000 \mathrm{~km}^{2}$, a seasonally flooded plain fed by tributaries of the Paraguay River, one of which is the MR (Galdino \& Silva 2006). The MR basin occupies an area of approximately $47,000 \mathrm{~km}^{2}$. It is $697 \mathrm{~km}$ long and runs in a southeast-northwest direction starting from Serra de Maracaju and empties into the Paraguay River. The MR and its tributaries usually carry a considerable concentration of alkaline earth cations. Salts are probably carried from abundant calcareous and dolomitic stone from the highlands of the Bodoquena and Maracaju-Campo Grande Mountains (Oliveira \& Ferreira 2003, Galati et al. 2006). All along the margins of the MR and its tributaries, numerous lakes of various sizes, bordered by large swamps, are formed during the flood season. On the margins and flooded ground of these lakes and swamps, where deciduous seasonal alluvial forests grow, are found abundant Holocenic alluvial deposits (Mendes et al. 2004). The annual mean rainfall is $1,102 \mathrm{~mm}$, with the highest indices reported from late October to March, and the driest period lasting from June to August-September (Galdino \& Silva 2006). The nearly flat land surface and slight elevation gra$\operatorname{dient}(3-15 \mathrm{~cm} / \mathrm{km}$ north $/$ south and $30-50 \mathrm{~cm} / \mathrm{km}$ east-west) of the MR basin favor flooding. The climate is classified as sub-humid megathermic, with a monthly mean temperature ranging from 18 to $28^{\circ} \mathrm{C}$, and an average annual relative humidity of $72.7 \%$, with the lowest values registered from
June to September (Artioli \& Resende 2005, Galdino \& Silva 2006). The soil is essentially composed of sediments that originated in the Bodoquena Mountains. Irrigated rice plantations and extensive cattle breeding are the most common economic activities.

Biting frequency - Animal-bait mosquito captures were performed bimonthly, from May 2006 to Mach 2007, for five successive days from 17:00 to 20:00 h, at two sites $\sim 200 \mathrm{~m}$ apart at the margin of the MR in Salobra. In May 2006, captures were also performed at a farm $\sim 500 \mathrm{~m}$ from MR. Captures were done directly from horse bait at one site and simultaneously with a horse-baited Shannon trap at the other site. Captured Anopheles mosquitoes belonging to the Triannulatus Complex were divided into two groups based on time of capture: (a) 17:00 h until sunset (H1), and (b) sunset to 20:00 h (H2). Other anopheline species and non-identifiable specimens belonging to the Triannulatus Complex (females that died just after collection) $(\mathrm{n}=687)$ were not considered.

Mosquito rearing and species identification - Most captured anophelines were already engorged. For those not engorged a blood source (sheep blood) was offered immediately after collection in order to obtain eggs. Adult females were identified to An. triannulatus s.l. (Consoli \& Lourenço-de-Oliveira 1994) and individually separated into labeled vials to oviposite. Progenies were reared separately (Silva-do-Nascimento \& Lourenço-de-Oliveira 2002). For each of the wild-caught females, morphological characters either from the P1 female or her progeny (eggs, fourth instar larva, male and female genitalia), as well as isoenzyme analyses (adult females), were performed for species identification (Silva-do-Nascimento \& Lourenço-de-Oliveira 2002, Silva-do-Nascimento et al. 2006).

Meteorological and hydrological data - Temperature, humidity and daily rainfall were recorded at a meteorological station at Bodoquena Farm, in Miranda. Daily records on the MR water level were obtained by the Agência Nacional de Águas of MS at the "Miranda Station" (post 66910000). The Miranda station is the closest hydrological station to the mosquito collection sites in Salobra. Water from two larval habitats in Salobra was sampled bimonthly (May 2006 to March 2007). Analyses included determination of salinity (\% of dissolved salt content), $\mathrm{pH}$, conductivity $(\mu \mathrm{S} / \mathrm{cm})$, oxygen (DO) and total dissolved solids (TDS, $\mathrm{mg} / \mathrm{l}$ ).

Statistical analysis - For each of the seven weeks before collection, the rainfall was summed and the relationships between biting frequency and total rainfall were tested for significant Spearman correlations. In addition, correlation analyses (Pearson correlation coefficient) between species biting frequency and the maximum water level recorded for the MR in Salobra 15, 30 and 60 days before collection were performed.

\section{RESULTS}

A total of 2,207 mosquito specimens belonging to the Triannulatus Complex was sampled: $794 \mathrm{An}$. triannulatus s.s. (35.9\%), 586 An. halophylus (26.6\%) 
and 827 An. triannulatus C (37.5\%). All three species belonging to the Triannulatus Complex were collected throughout the year (Table I, Fig. 1). However, distinct population fluctuations were detected. The highest biting frequency for An. triannulatus s.s. was in May, when rainfall was decreasing and the highest levels of the MR were recorded in Salobra. On the other hand, both $A n$. halophylus and An. triannulatus $\mathrm{C}$ showed the highest biting frequency in July, in the middle of the dry season, when both the MR water level and rainfall typically decreased. Significant positive Pearson correlations were found between biting frequency of An. triannulatus s.s. and water level of the MR (maximum level) recorded at 30 days $\left(\mathrm{r}=0.824, \mathrm{r}^{2}=68 \%\right)$, and 60 days $\left(\mathrm{r}=0.908, \mathrm{r}^{2}\right.$ $=83 \%$ ). For An. halophylus, no Pearson correlation was observed between biting frequency and river level recorded at $15(\mathrm{r}=-0.23), 30(\mathrm{r}=0.017)$ or 60 days $(\mathrm{r}=0.189)$. Negative correlations were found between biting frequency of An. triannulatus $\mathrm{C}$ and water level of the MR recorded $15(\mathrm{r}=-0.256)$ and 30 days $(\mathrm{r}=-0.025)$ before mosquito capture; but no correlation was found for records 60 days before $\left(r=0.229, r^{2}=5 \%\right)$. The biting frequency of the three species was negatively influenced by rainfall. This can be seen more clearly in collection data from January, when the lowest anopheline biting frequencies and highest rainfall were recorded (Figs 1 and 2). Biting frequency of An. triannulatus was significantly inversely correlated with rainfall two and six weeks (between 8 and 14 days, and 36 and 42 days, respectively) before collection dates (Table II). Biting frequency of both $A n$. halophylus and An. triannulatus $\mathrm{C}$ were significantly negatively correlated with rainfall except between 15 and 21 days.

Taking into account the results of all collections, we noted that activity of both An. triannulatus and An. triannulatus $\mathrm{C}$ peaked after sunset, while An. halophylus bit almost as frequently early as late in the evening (Fig. $3)$. In May, all three species showed a higher biting frequency at $\mathrm{H} 1$ rather than late in the evening (Figs 3 and

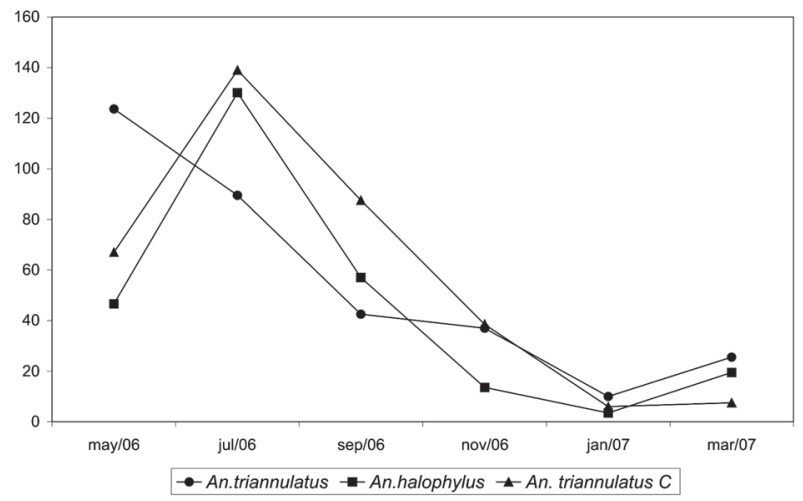

Fig. 1: bimonthly frequency of Anopheles species of the Triannulatus Complex in Salobra, Mato Grosso do Sul, Brazil, from May 2006 to March 2007. Frequency is given as mean of specimen per collector.

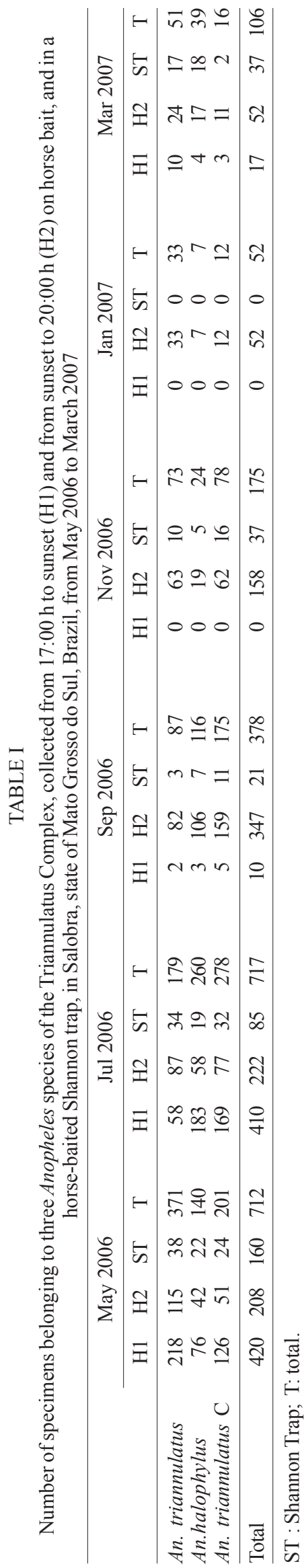



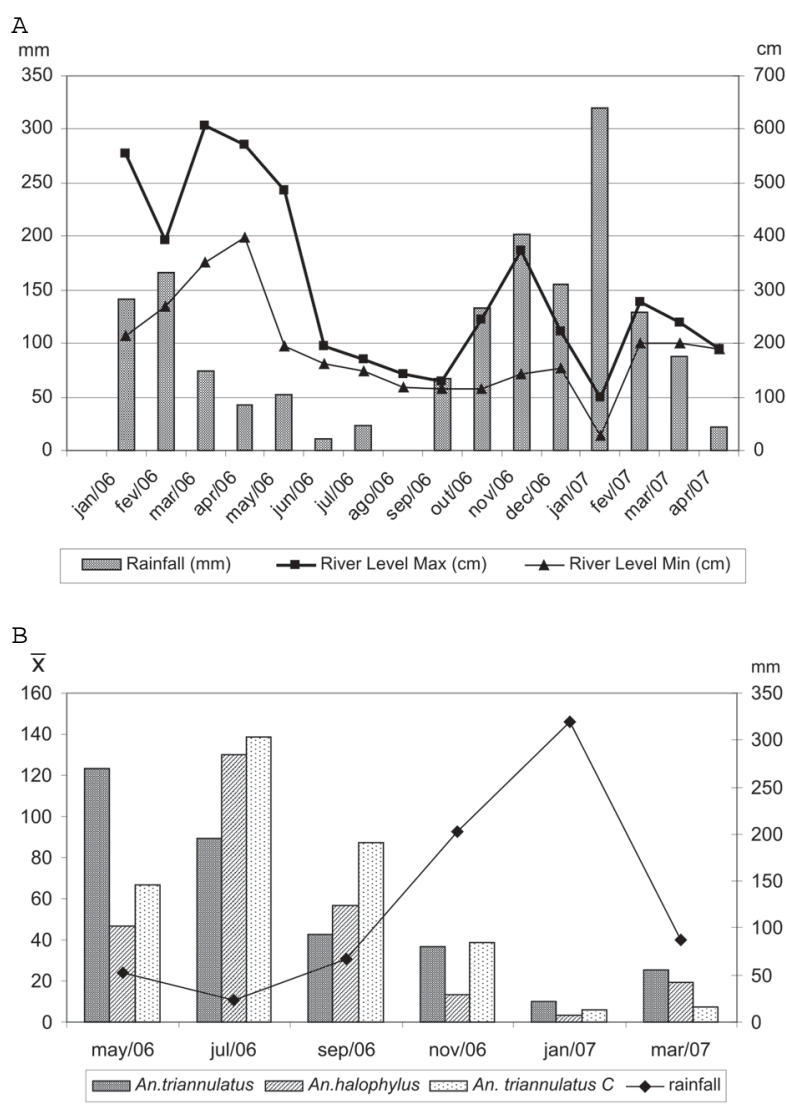

Fig. 2: Miranda River water level and rainfall (A) from January 2006 to April 2007, and bimonthly rainfall and the mean number of specimens of three Anopheles species of the Triannulatus Complex (B) from May 2006 to March 2007, in Salobra, Mato Grosso do Sul, Brazil.

4). In July, when the length of the day is short in the region, An. halophylus and An. triannulatus $\mathrm{C}$ presented even higher frequencies at $\mathrm{H} 1$, while An. triannulatus was collected in similar numbers at $\mathrm{H} 1$ and H2. From November to March, the period when days and nights are of almost equal length in Central Brazil, all species had basically a similar biting frequency regardless of capture times.

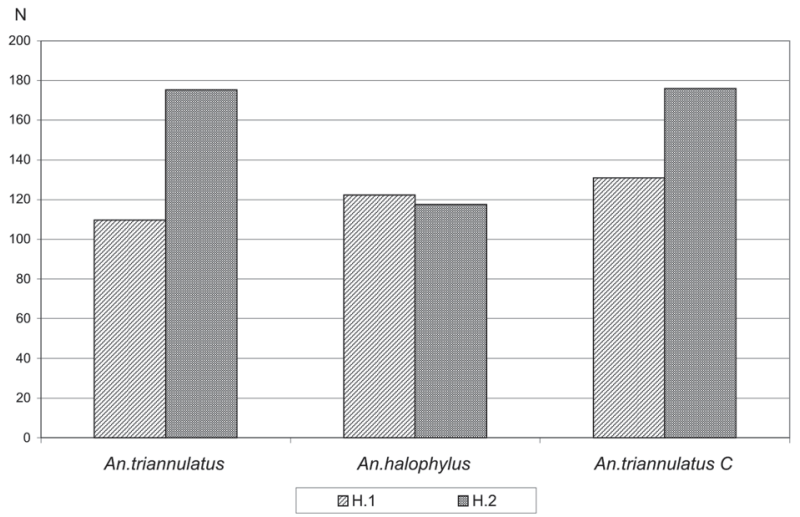

Fig. 3: specimens of An. triannulatus s.s., An. halophylus and An. triannulatus $\mathrm{C}$ collected from 17:00 $\mathrm{h}$ to sunset $(\mathrm{H} 1)$ and from sunset to 20:00 h (H2) in Salobra, Mato Grosso do Sul, Brazil, from May 2006 to March/2007.

Meteorological and hydrological data - There were no differences in $\mathrm{DO}$ or $\mathrm{pH}$ from water samples from two larval habitats during the year. Conductivity and TDS were higher in the transition period between rainy and dry seasons. Salinity exhibited strong variation and was negatively influenced by rainfall (Fig. 5). The highest degree of salinity was recorded in May (1.3\%). This corresponds to the beginning of the dry season and the highest levels of the MR. Salinity was slightly lower but still high in July (1.0\%) but strongly decreased (0.1\%) with increased rainfall from September to March.

\section{DISCUSSION}

Ecological and biological differences in types of larval habitats, seasonality and behavior may occur in species belonging to species complexes within their geographical distributions that can be related to local environmental characteristics. Thus, differences in population dynamics and behavior between sibling species are only suitably analyzed when these species occur in sympatry (Obsomer et al. 2007). Few sympatric Anopheles sibling species complexes have been studied. Herein, the population fluctuation of three sympatric members of the Triannulatus Complex was evaluated.

TABLE II

Results of Spearman's rank correlation analyses between frequency of three Anopheles species of the Triannulatus Complex and weekly rainfall during six intervals before the field collections

Week Intervals

before collections An. triannulatus

An. halophylus

An. triannulatus $\mathrm{C}$

\begin{tabular}{|c|c|c|c|c|c|c|}
\hline & $\rho$ & $\mathrm{p}$ & $\rho$ & $\mathrm{p}$ & $\rho$ & $\mathrm{p}$ \\
\hline 1 to 7 & $-0,314$ & 0,103 & $-0,417^{a}$ & $0,027^{b}$ & $-0,425^{a}$ & $0,024^{b}$ \\
\hline 8 to 14 & $-0,596^{a}$ & $0,000^{b}$ & $-0,589^{a}$ & $0,000^{b}$ & $-0,625^{a}$ & $0,000^{b}$ \\
\hline 15 to 21 & $-0,173$ & 0,377 & $-0,148$ & 0,450 & 0,106 & 0,591 \\
\hline 22 to 28 & $-0,267$ & 0,168 & $-0,528^{a}$ & $0,003^{b}$ & $-0,541^{a}$ & $0,002^{b}$ \\
\hline 29 to 35 & $-0,320$ & 0,096 & $-0,529^{a}$ & $0,003^{b}$ & $-0,632^{a}$ & $0,000^{b}$ \\
\hline 36 to 42 & $-0,542^{a}$ & $0,002^{b}$ & $-0,607^{a}$ & $0,000^{b}$ & $-0,707^{a}$ & $0,000^{b}$ \\
\hline
\end{tabular}

$a$ : Spearman's rank correlation coefficients significantly different from zero; $b: \mathrm{p} \leq 0.05$. 

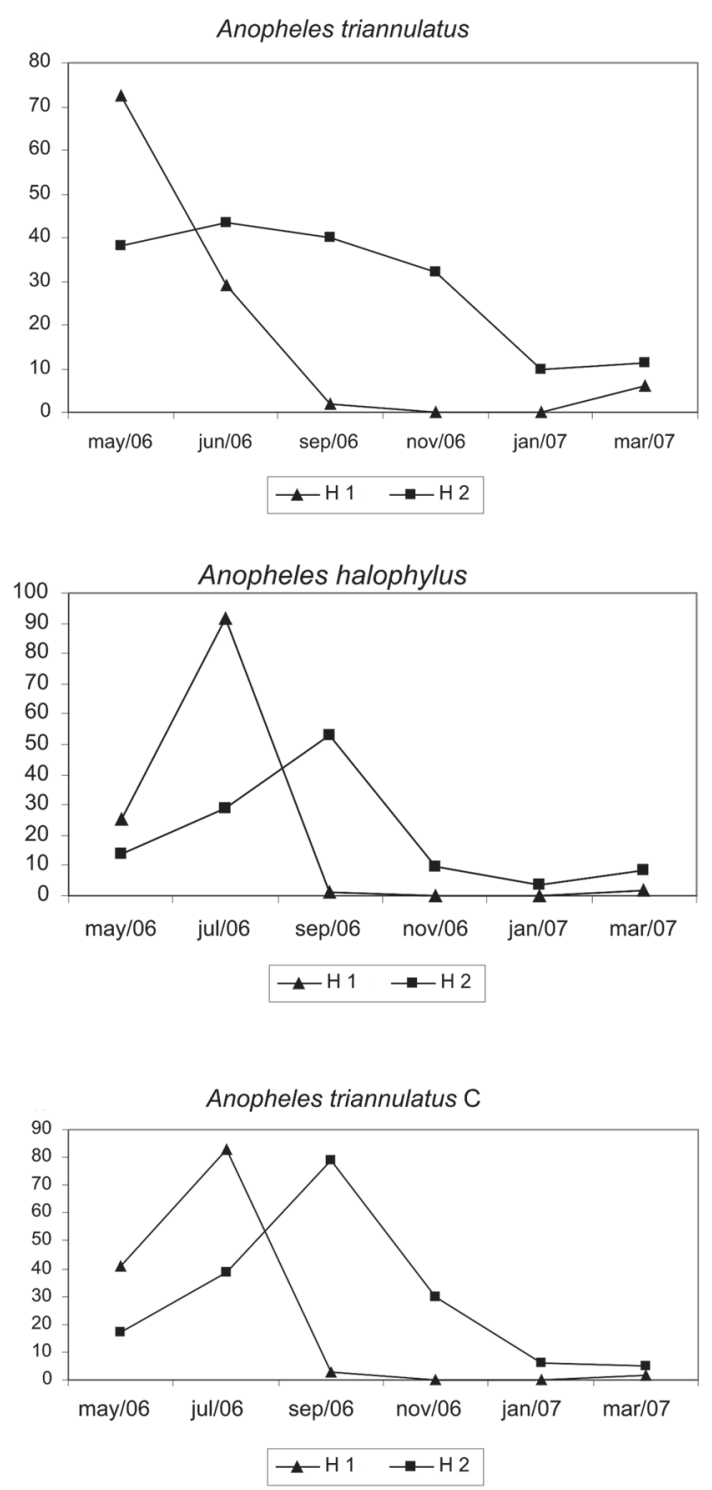

Fig. 4: bimonthly frequency of three Anopheles species of the Triannulatus Complex. Frequency is given as mean of specimens per collector captured from 17:00h to sunset (H1) and from sunset to 20:00 h (H2), in Salobra, Mato Grosso do Sul, Brazil, from May 2006 to March 2007.

Our year-round collections in Salobra showed that all three species bit more frequently late in the evening, although An. halophylus was collected in similar numbers early and late in the evening (Fig. 3). Distinct hourly biting patterns were recorded for the species throughout the year (Fig. 4). The biting time of a mosquito species at a given location is dependent on the relationship between inherited endogenous oscillators and local environmental and physiological factors such as age of the population, moon phase, rainfall, and distance from the oviposition or mating site (Charlwood 1996, Obsomer et al. 2007). During seasonal population peaks of a mosquito species, a large proportion of the biting individuals consists of young nuliparous females. Early evening biting activity has been observed during population peaks for other Neotropical anophelines (Elliot 1972, Klein \& Lima 1990). Charlwood and Wilkes (1979) found that the individuals of Anopheles darlingi that were biting in the crepuscular peaks observed in Mato Grosso consisted largely of nulliparous females. In considering the population peak of each species of the Triannulatus Complex, we observed that a higher number of specimens were collected at H1. Contrasting, in off peak periods, these three species tended to be more frequent after sunset (H2). Although hourly captures were not conducted in the present study, An triannulatus s.l. biting activity peaked shortly after sunset, however, it continued into the night (data not shown).

The seasonal frequency of An. triannulatus s.l. is known to vary throughout South America. Brazilian populations of An. triannulatus s.l. generally peak during the rainy season or during the transitions between rainy and dry seasons (Ianelli et al. 1998, Xavier \& Rebêlo 1999, Souza-Santos 2002). In Venezuela and Argentina, larval density increased in the beginning and in the middle of the dry season, respectively (Rubio-Palis et al. 2005, Stein et al. 2004). In Bolivia however, larval density peaked in the rainy season (Rejmánková et al. 1999). These distinct seasonal variations may be due to characteristics of different members of the Triannulatus Complex. Additionally, the influence of geographical variation in seasonal rainfall, river levels, temperatures, abundance of larval habitats and of floating vegetation, may affect population dynamics for any given species of the Triannulatus Complex. An. triannulatus s.s. seems to be more common and widespread in South and Central America than the other members of the complex (Deane et al. 1948, Faran 1980, Faran \& Linthicum 1981, Silvado-Nascimento \& Lourenço-de-Oliveira 2002). Nevertheless, specimens morphologically identifiable to $A n$. halophylus and/or to An. triannulatus $\mathrm{C}$ have been collected in three states in the Brazilian Amazon (Rondônia, Acre, Amazonas and Pará) and in Paraguay and Bolivia (Deane et al. 1947, 1948, Root 1926).

In the present study, distinct seasonal biting frequencies were exhibited by three sympatric members of the Triannulatus Complex in Salobra. Biting frequency of all three species was shown to be negatively influenced by rainfall. A noteworthy reduction in biting frequency for the three species was detected during the rainy season (November to March). The decrease in biting frequency of An. triannulatus s.l. was striking for January 2007, when an unusual increase in rainfall was recorded (Fig. 2). Increasing precipitation in the rainy season probably impacts negatively on their population density in Salobra due to flushing and strong physicochemical changes in water characteristics at breeding sites. High numbers of temporary larval habitat mosquito breeders such as Psorophora and Aedes were noticed in January (data not shown). Strong decrease in biting frequency for $A n$. triannulatus s.l. during the rainy season in Salobra was also described approximately 60 years ago: 2,666 specimens were collected at the beginning of the dry (and malarious) season, whereas only three were obtained in the summit of the rainy season (Travassos \& Teixeira de Freitas 
1940, Travassos 1940, Galvão \& Lane 1941). We observed that frequency of all three species tended to decline as water impoundments subsided late in the dry season.

In Salobra, the population of An. triannulatus s.s. seems to peak immediately after the long rainy season. Notably, this peak occurs just after flooding of the lowlands by the MR and tributaries that induce the formation of large and permanent marshes with abundant vegetation. On the other hand, An. halophylus and An. triannulatus $\mathrm{C}$ populations peak later, when natural water impoundments no longer receive inflow from the MR and are therefore somewhat reduced in size. Water impoundment size reduction is probably related to the combined effect of evaporation and low rainfall (Figs 1 and 2). Anopheles halophylus and An. triannulatus $\mathrm{C}$ seem to be more closely related to each other than either is to An. triannulatus s.s. (Silva-do-Nascimento et al 2006). Coincidently, differences in population dynamics were greater between An. triannulatus s.S. and An. halophylus and An. triannulatus $\mathrm{C}$ than between An. halophylus and An. triannulatus C.

The highest biting frequency for An. triannulatus s.s. occurred in May 2006 (Figs 1 and 2). Peaks of high water levels in MR have been recorded in Salobra since March 2006. These peaks of river flow were found to be high enough to flood large low-lying expanses around Salobra. Therefore, an increase in An. triannulatus s.l. population in Salobra seems to be positively correlated with the formation of abundant large stable and permanent marshes subsequent to flooding of the MR and tributaries. Coincidently, higher biting frequencies of $A n$. triannulatus s.l. following flooding during reservoir replenishment periods have been reported in Southwest and Central Brazil (Teodoro et al. 1995, Guimarães et al. 2004). During flow peak and river flooding periods in Salobra, great variation in river level is observed within short periods ( 2 - 3 days). Perceptible differences were detected by monthly low and high MR levels records (Fig. 2).

Larvae of An. halophylus were collected in sunlit marshes with abundant floating vegetation and high concentrations of sodium chloride (Silva-do-Nascimento \& Lourenço-de-Oliveira 2002). One of the important tributaries of the MR is the Salobra River (SR), which has water with a notable chemical characteristic. It has high concentration of electrolytes $\left(\mathrm{Ca}^{++}\right.$and $\left.\mathrm{Mg}^{++}\right)$, and bicarbonate ions are the main anion (Oliveira \& Ferreira 2003). The high concentration of alkaline earth cations carried by the SR waters probably is a result of an abundance of calcareous and dolomitic rock in the Botoquena Mountains (Oliveira \& Ferreira 2003). The SR joins the MR just at Salobra, where large marshes and lakes of fresh to brackish water with sparse to abundant floating vegetation are formed during the flooding period due to overflow of a mixture of waters from the SR and MR. Coincidently, both An. halophylus and An. triannulatus C peaked in the dry season (July), when these marshes and lakes are smaller, since there is no water coming from the surrounding rivers and precipitation is scarce. As a result there is an increase in ion and salt concentrations and that become stable in most larval habitats, which may be favorable to An. halophylus and An. triannulatus C.
Additionally, the soil at Salobra is essentially composed of salty and calcareous sediments originated in the Bodoquena Mountains. Thus salts from the soil may also be dissolved in the water of flooded plains, and consequently several local marshes have moderate to high salt concentrations. These water bodies in Salobra are often classified as brackish water. Waters are classified as brackish when salinity is from 0.05 to $3 \%$ (= $500-30,000 \mathrm{ppm}$ ) (CONAMA 2000). In fact, continuous evaluation in one of the water impoundments at Salobra showed salinity ranging from 0.1 to $1.3 \%$ (Fig. 5).

Published biological and ecological data in the literature regarding to An. triannulatus from South and Central America may potentially correspond to one, two, or more species of the Triannulatus Complex. The distinctive population dynamics reported herein suggest either the exploitation of different larval habitats or ecological niches by the Triannulatus Complex species during the speciation process. Ayala and Coluzzi (2005) suggested that complete reproductive isolation in the Anopheles gambiae Complex was subsequent to specialization of the different species to separate niches. Immature niche partitioning for the three species of the Triannulatus Complex has not been evaluated yet. Diabaté et al. (2005) suggested that spatial segregation between the $\mathrm{M}$ and $\mathrm{S}$ forms of An. gambiae s.s. may be not determined by differences in their exploitation of the physical and chemical characteristics of larval habitats. Baimai et al. (1988) showed that sympatric populations of two species in the Anopheles dirus complex may share identical larval habitat and even the same pools in Thailand, while a third member is more often found in pools that dried out in dry spells during the rainy season. Our data showed similar seasonal population density of the most closely related forms in the Triannulatus Complex - $A n$. halophylus and An. triannulatus C. This may suggest that these two closely related forms may exploit larval habitats with similar characteristics, i.e. with the same physicochemical conditions, or even share the same larval habitats. Associations between immatures of Anopheles belonging to the Triannulatus Complex within larval habi-

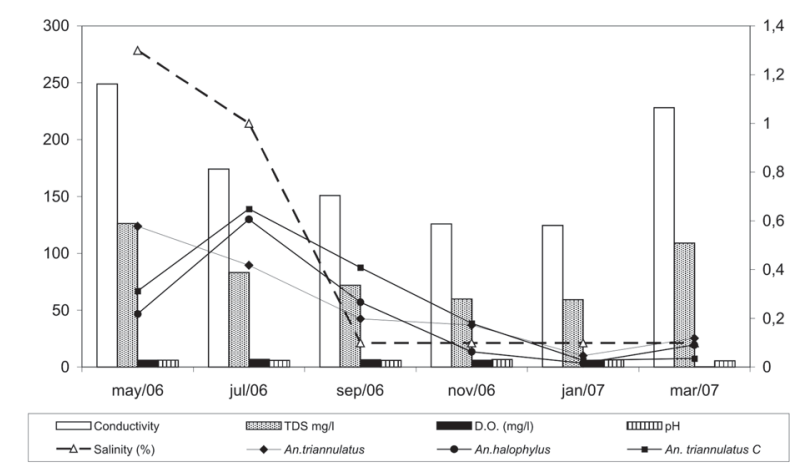

Figure 5: chemical parameters of the water from two larval habitats and number of specimens of three Anopheles species of the Triannulatus Complex collected in Salobra, Mato Grosso do Sul, Brazil, from May 2006 to March 2007. 
tats need to be investigated. Larval habitats need to be characterized, taking in account varying conditions of water physicochemical characteristics, as well as rainfall and inundation dynamics in flood-prone areas.

\section{ACKNOWLEDGMENTS}

To Maria Goreti Rosa-Freitas for critical reading of the manuscript, Rafael Maciel-de-Freitas for the help in the statistical analysis, Andiaria Ramos da Silva and Maycon S A S Neves for laboratory assistance, Marcelo Quintela Gomes and Glauber Rocha for field and laboratory assistance, Fazenda Bodoquena for providing meteorological and environmental data, Darcílio F Baptista and Thaissa Alves for chemical analysis of water, and Agência Nacional de Águas for the daily records of MR water levels.

\section{REFERENCES}

Artioli AP, Resende EK 2005. Ocupação das matas ciliares pelos empreendimentos do turismo de pesca no rio Miranda, Pantanal, Brasil. In Embrapa, Boletim de Pesquisa e Desenvolvimento 64 - EMBRAPA/CPAP, p. 1-31.

Ayala FJ, Coluzzi M 2005. Chromosome speciation: humans, Drosophila, and mosquitoes. Proc Natl Acad Sci 102: 6535-6542.

Baimai V, Kijchalao U, Sawadwongporn P, Green CA 1988. Geographic distribution and biting behaviour of four species of the Anopheles dirus complex (Diptera: Culicidae) in Thailand. Southeast Asian J Trop Med Pub Health 19: 151-161.

Branquinho MS, Lagos CB, Rocha RM, Natal D, Barata JM, Cochrane AH, Nardin E, Nussenzweig RS, Kloetzel JK 1993. Anophelines in the state of Acre, Brazil, infected with Plasmodium falciparum, $P$. vivax, the variant $P$. vivax VK247 and P. malariae. Trans R Soc Trop Med Hyg 87: 391-394.

Brochero H, Pareja PX, Ortiz G, Olano VA 2006. Breeding places and biting activity of Anopheles species in the municipality of Cimitarra, Santander, Colômbia. Biomedica 26: 269-277.

Cerqueira NL 1961. Distribuição geográfica dos mosquitos da Amazônia. Rev Bras Entomol 10: 111-168.

Chadee DD, Wilkerson RC 2005. Anopheles triannulatus (Neiva and Pinto): A new Anopheles record from Trinidad, West Indies. J Am Mosq Control Assoc 21: 316-317.

Charlwood JD 1996. Biological variation in Anopheles darlingi Root. Mem Inst Oswaldo Cruz 91: 391-398.

Charlwood JD, Wilkes TJ 1979. Studies on the age-composition of samples of Anopheles darlingi Root (Diptera: Culicidae) in Brazil. Bull Entomol Res 69: 337-342.

Charlwood JD, Wilkes TJ 1981. Observations on the biting activity of Anopheles triannulatus bachmanni from the Mato Grosso, Brazil. Acta Amaz 11: 67-69.

Coluzzi M, Sabatini A, Petrarca V, Di Deco MA 1979. Chromosomal differentiation and adaptation to human environments in the Anopheles gambiae complex. Trans R Soc Trop Med Hyg 73: 483-497.

CONAMA - Conselho Nacional de Meio Ambiente 2000. Resolução Conama n. 274, Brasília, DF [cited 2007 July 20]. Available from: http://www.cetesb.sp.gov.br/Agua/praias/ res_conama_274_00.pdf.

Consoli RAGB, Lourenço-de-Oliveira R 1994. Principais mosquitos de importância sanitária no Brasil, Rio de Janeiro, Fiocruz, $225 \mathrm{pp}$.

Deane LM, Causey OR, Deane MP 1947. Chave ilustrada para a identificação de ovos de 30 espécies de anofelinos brasileiros, com algumas descrições novas. Rev Serv Esp Saúde Públ 1: 293-308.

Deane LM, Causey OR, Deane MP 1948. Notas sôbre a distribuição e a biologia dos anofelinos das regiões nordestinas e amazônica do Brasil. Rev Serv Esp Saúde Públ 1: 827-965.

Diabaté A, Dabire R K, Kim E H, Dalton R, Millogo N, Baldet T, Simard F, Gimnig J E, Hawley W A, Lehmann T 2005. Larval development of the molecular forms of Anopheles gambiae (Diptera: Culicidae) in different habitats: a transplantation experiment. J Med Entomol 42: 584-563.

Edillo FE, Touré YT, Lanzaro GC, Dolo G, Taylor CE 2004. Survivorship and distribution of immature Anopheles gambiae s.1. (Diptera: Culicidae) in Banambani village, Mali. J Med Entomol 41: 333-339.

Edillo FE, Tripet F, Touré YT, Lanzaro GC, Dolo G, Taylor CE 2006. Water quality and immatures of the $\mathrm{M}$ and $\mathrm{S}$ forms of Anopheles gambiae s.s. and An. arabiensis in a Malian village. Malar J 5: 35.

Elliott R 1972. The influence of vector behaviour on malaria transmission. Am J Trop Med Hyg 21: 755-763.

Faran ME 1980. Mosquitos Studies (Díptera, Culicidae) XXXIV.A revision of the Albimanus Section of the subgenus Nyssorhynchus of Anopheles. Contrib Amer Ent Inst 15: 1-215.

Faran ME, Linthicum KJ 1981. A handbook of the Amazonian species of Anopheles (Nyssorhynchus) (Diptera, Culicidae). Mosq Syst 13: 1-81.

Galardo AK, Arruda M, D'Almeida Couto AA, Wirtz R, Lounibos LP, Zimmerman RH 2007. Malaria vector incrimination in three rural riverine villages in the Brazilian Amazon. Am J Trop Med Hyg 76: 461-469.

Galati EAB, Nunes VLB, Boggiani PC, Dorval MEC, Cristaldo G, Rocha HC, Oshiro ET, Damasceno-Junior G 2006. Phlebotomines (Diptera: Psychodidae) in forested areas of the Serra da Bodoquena, state of Mato Grosso do Sul, Brazil. Mem Inst Oswaldo Cruz 101: 175-193.

Galdino S, Silva JS 2006. Análise da inundação de agosto de 1998 à jusante da cidade de Miranda, MS, no Pantanal. Anais do Primeiro Simpósio de Geotecnologias no Pantanal, EMPRAPA Informática Agropecuária/INPE, Campo Grande, MS, p. 67-76.

Galvão ALA, Lane J 1941. Observações sobre alguns anofelinos de Salobra, Mato Grosso (Diptera: Culicidae). Rev Biol Hyg 11: $10-18$.

Guimarães AE, Gentile C, Alencar J, Lopes CM, de Mello RP 2004. Ecology of Anopheline (Diptera, Culicidae), malaria vectors around the Serra da Mesa Reservoir, State of Goiás, Brazil. 1- Frequency and climatic factors. Cad Saude Publica 20: 291-302.

Ianelli RV, Honório NA, Lima DC, Lourenço-de-Oliveira R, Santos RV, Coimbra Júnior CE 1998. Faunal composition and behavior of anopheline mosquitoes in the Xavánte Indian reservation of Pimentel Barbosa, central Brazil. Parasite 5: 197-202.

Klein TA, Lima JBP 1990. Seasonal distribution and biting patterns of Anopheles mosquitoes in Costa Marques, Rondônia, Brazil. J Am Mosq Control Assoc 6: 700-707.

Lopes J, Lozovei AL 1995. Ecologia de mosquitos (Díptera: Culicidae) em criadouros naturais e artificiais de área rural do norte do estado do Paraná, Brasil. I. Coletas ao longo do leito do ribeirão. Rev Saude Publ 29: 183-191. 
Lourenço-de-Oliveira R, Guimarães AEG, Arlè M, Silva TF, Castro MG, Motta MA, Deane LM 1989. Anopheline species, some of their habits and relation to malaria in endemic areas of Rondonia State, Amazon region of Brazil. Mem Inst Oswaldo Cruz 84: 501-514.

Lourenço-de-Oliveira R, Luz SLB 1996. Simian malaria at two sites in the Brazilian Amazon - II. Vertical distribution and frequency of anopheline species inside and outside the forest. Mem Inst Oswaldo Cruz 91: 687-694.

Mendes CAB, Grehs SA, Pereira MCB, Barreto SR, Becker M, Lange MBR, Dias FA 2004. Bacia Hidrográfica do Rio Miranda. Estado da Arte. Universidade Católica Dom Bosco, Campo Grande, 177 pp.

Obsomer V, Defourny P, Coosemans M 2007. The Anopheles dirus complex: spatial distribution and environmental drivers. Malar J 6: 26

Oliveira-Ferreira J, Lourenco-de-Oliveira R, Teva A, Deane LM, Daniel-Ribeiro CT. 1990. Natural malaria infections in anophelines in Rondonia State, Brazilian Amazon. Am J Trop Med Hyg 43: 6-10.

Oliveira MD, Ferreira CJ 2003. Estudos limnológicos para o monitoramento da bacia hidrográfica do rio Miranda, Pantanal sul. Boletim de Pesquisa e Desenvolvimento 54 Embrapa, Cuiabá, 62 p.

Póvoa MM. Souza RTL, Lacerda RNL, Rosa ES, Galiza D, Souza JR, Wirtz R, Schlichting CD, Conn JE 2006. The importance of Anopheles albitarsis E and An. darlingi in human malaria transmission in Boa Vista, state of Roraima, Brazil. Mem Inst Oswaldo Cruz 101: 163-168.

Póvoa M, Wirtz R, Lacerda R, Miles M, Warhurst D 2001. Malaria vectors in the municipality of Serra do Navio, State of Amapá, Amazon Region, Brazil. Mem Inst Oswaldo Cruz 96: 179-184.

Rebêlo JM, Silva AR, Ferreira LA, Vieira JA 1997. Anopheles (Culicidae, Anophelinae) e a malária em Buriticupu-Santa Luzia, Pré-Amazônia Maranhense. Rev Soc Bras Med Trop 30: 107-111.

Rejmánková E, Rubio-Palis Y, Villegas L 1999. Larval habitat of Anopheline mosquitoes in the Upper Orinoco, Venezuela. $J$ Vector Ecol 24: 130-137.

Ribeiro ALM 2000. Aspectos ecológicos de criadouros de anofelinos em áreas de garimpos abandonados nos municípios de Matupá e Peixoto Azevedo/MT. MSc Thesis. Universidade Federal do Mato Grosso, Cuiabá, 61 pp.

Root FM 1926. Studies on Brazilian mosquitoes. I. Anophelines of the Nyssorhynchus group. Am J Hyg 6: 684-717.

Rosa-Freitas MG, Tsouris P, Peterson AT, Honório NA, Barros FSM, Aguiar DB, Gurgel HC, Arruda ME, Vasconcelos SD, Luitgards-Moura JF 2007. An ecoregional classification for the state of Roraima, Brazil: the importance of landscape in malaria biology. Mem Inst Oswaldo Cruz 102: 349-358.
Rubio-Palis Y, Menare C, Quinto A, Magris M, Amarista M 2005. Caracterización de criaderos de anofelinos (Diptera: Culicidae) vectores de malaria del Alto Orinoco, Amazonas, Venezuela. Entomotropica 20: 29-38.

Silva AM 2002. Imaturos de mosquitos (Díptera, Culicidae) de áreas urbana e rural no norte do estado do Paraná, Brasil. Iheringia Ser Zool 92: 31-36.

Silva-do-Nascimento T, Lourenço-de-Oliveira R 2002. Anopheles halophylus, a new species of the subgenus Nyssorhynchus (Diptera: Culicidae) from Brazil. Mem Inst Oswaldo Cruz 97: 801-811.

Silva-do-Nascimento T, Wilkerson RC, Lourenço-de-Oliveira R, Monteiro FA 2006. Molecular confirmation of the specific status of Anopheles halophylus (Díptera: Culicidae) and evidence of a new criptic species within An. triannulatus in Central Brazil. J Med Entomol 43: 455-459.

Souza-Santos R 2002. Distribuição Sazonal de vetores da malária em Machadinho d' Oeste, Rondônia, região Amazônica. Cad. Saude Publica 18: 1813-1818.

Stein M, Almirón WR, Willener JA, Gorodner JO 2004. Variación temporal de formas imaturas (Díptera:Culicidae) en la Provincia del Chaco. Comunicaciones Cientificas y Technológicas B-043. Universidad Nacional del Nordeste, Resistência, Chaco, Argentina.

Tadei WP, Dutary-Thatcher B 2000. Malaria vectors in the Brazilian Amazon: Anopheles of the subgenus Nyssorhynchus. Rev Inst Med Trop São Paulo 42: 87-94.

Tadei WP, Tatcher BD, Santos JMM, Scarpassa VM, Rodrigues IB, Rafael MS 1998. Ecologic observations on anopheline vectors of malaria in the Brazilian Amazon. Am J Trop Med Hyg 59: 325-335.

Teodoro U, Guilherme ALF, Lozovei AL, Filho VLS, Fukushigue Y, Spinosa RP, Ferreira MEMC, Barbosa OC, Lima EM 1995. Culicídeos do lago de Itaipu, no rio Paraná, sul do Brasil. Rev Saude Publ 29: 6-14.

Travassos L 1940. I- Introdução. Relatório da terceira excursão à zona da estrada de ferro Noroeste do Brasil realizada em Fevereiro e Março de 1940. Mem Inst Oswaldo Cruz 35: 607-713.

Travassos L, Teixeira de Freitas JF 1940. Relatório da excursão realizada na zona da Estrada de Ferro Noroeste do Brasil em julho de 1939. Mem Inst Oswaldo Cruz 35: 525-556.

Xavier MM, Rebêlo JM 1999. Species of Anopheles (Culicidae, Anophelinae) in a malaria-endemic area, Maranhão, Brazil. Rev Saude Publ 33: 535-541.

Zimmerman RH, Galardo AK, Lounibos LP, Arruda M, Wirtz R 2006. Blood meal hosts of Anopheles species (Diptera: $\mathrm{Cu}-$ licidae) in a malaria-endemic area of the Brazilian Amazon. $J$ Med Entomol 43: 947-56. 